Article

\title{
Two Supramolecular Inorganic-Organic Hybrid Crystals Based on Keggin Polyoxometalates and Crown Ethers
}

\author{
Jun Xiong ${ }^{1, *}$, Teng Luo ${ }^{1}$, Jun Zhang ${ }^{1}$, Xiao-Xia Li ${ }^{1}$, Shao-Fang Lv ${ }^{1}$, Jun-Jun Peng ${ }^{1}$, Ming Li ${ }^{1}$, \\ Wei $\mathrm{Li}^{1}$ and Takayoshi Nakamura ${ }^{2,3, *}$ \\ 1 College of Chemistry and Chemical Engineering, Wuhan Textile University, Wuhan 430200, China; \\ tengluo136@163.com (T.L.); junzhang0903@163.com (J.Z.); lixxwh@163.com (X.-X.L.); \\ 2007103@wtu.edu.cn (S.-F.L.); john_peng@wtu.edu.cn (J.-J.P.); lim@wtu.edu.cn (M.L.); \\ liwei@wtu.edu.cn (W.L.) \\ 2 Graduate School of Environmental Science, Hokkaido University, Sapporo 060-0812, Japan \\ 3 Research Institute for Electronic Science, Hokkaido University, Sapporo 001-0020, Japan \\ * Correspondence: jxiong@wtu.edu.cn (J.X.); tnaka@es.hokudai.ac.jp (T.N.)
}

Received: 13 December 2017; Accepted: 19 January 2018; Published: 23 January 2018

\begin{abstract}
New supramolecular structures were designed in this work using large-sized polyoxometalates (POMs) and crown-ether-based supramolecular cations selected as building blocks. Two novel supramolecular inorganic-organic hybrids [(3-F-4-MeAnis)([18]crown-6) $]_{2}\left[\mathrm{SMo}_{12} \mathrm{O}_{40}\right] \bullet \mathrm{CH}_{3} \mathrm{CN}(\mathbf{1})$ and [(4-IAnis)([18]crown-6) $]_{3}\left[\mathrm{PMo}_{12} \mathrm{O}_{40}\right] \bullet 4 \mathrm{CH}_{3} \mathrm{CN}$ (2) (3-F-4-MeAnis = 3-fluoro-4-methylanilinium and 4-IAnis = 4-iodoanilinium) were synthesized. Crystals 1 and $\mathbf{2}$ have been characterized by infrared spectroscopy (IR) and elemental analysis (EA). Based on X-ray diffraction analysis, Crystals 1 and 2 were constructed through noncovalent bonding interactions and belong to different space groups due to the difference of the building blocks used. Supramolecular cations formed due to strong $\mathrm{N}-\mathrm{H} \cdots \mathrm{O}$ hydrogen bonding interactions between the six oxygen atoms of [18]crown-6 molecules and nitrogen atoms of anilinium derivatives. Crystal 1 has two different supramolecular cations with an anti-paralleled arrangement that forms a dimer through weak hydrogen bonding interactions between adjacent [18]crown-6 molecules. Crystal 2 has three independent supramolecular cations that fill large spaces between the $\left[\mathrm{PMo}_{12} \mathrm{O}_{40}\right]$ polyoxoanions forming a rhombus-shape packing arrangement in the ac plane. Crystals $\mathbf{1}$ and $\mathbf{2}$ are unstable at room temperature.
\end{abstract}

Keywords: supramolecular chemistry; inorganic-organic hybrids; polyoxometalates; crown ethers

\section{Introduction}

Crystal engineering, to create desired functional materials, involves the design of versatile crystal architectures based on molecular building blocks via a self-assembly process [1-3]. Over the past several decades, crystal engineering has attracted much attention not only because of the versatile structures but also due to the far ranging applications such as those in nonlinear optical, magnetic, and catalytic fields [4-7].

Supramolecular crystal structures in crystal engineering can be utilized in the construction of molecular machines and ferroelectric domains [8-10]. The first and key step in making functional materials is to design a desired versatile supramolecular structure. Supramolecular crystal structures are constructed through noncovalent bonding interactions. The hydrogen bonding interaction is a significant force that can connect building blocks in different forms and affect the crystal structure [11]. In addition, the molecular packing can be adjusted by changing crystal building blocks to control the strength of intermolecular hydrogen bonding interactions [12,13]. Furthermore, electrostatic 
interaction is another type of noncovalent interaction that can help to modify the molecular packing mode by changing the charge of the building blocks [14,15].

Supramolecular inorganic-organic hybrid materials have been of great interest due to their architecture and potential physicochemical applications. One unique advantage of constructing such a supramolecular structure is combining the structural features of inorganic and organic building blocks. Polyoxometalates (POMs) composed of discrete early transition metal-oxide cluster anions possess many structural advantages for constructing supramolecular structures. First, POMs contain numerous exposed oxygen atoms which can act as potential hydrogen bonding interaction sites [16-18]. Lindqvist $\left[\mathrm{Mo}_{6} \mathrm{O}_{19}\right]$ polyoxoanions, for example, contain three types of oxygen atoms: the exposed terminal oxygen $\mathrm{O}_{t}$, the bridging oxygen $\mathrm{O}_{b}$, and the central oxygen $\mathrm{O}_{c}$. The exposed oxygen atoms $\left(\mathrm{O}_{t}\right.$ and $\left.\mathrm{O}_{b}\right)$ are potential hydrogen bonding interaction sites. Moreover, the charge of POMs can be modified by a chemical method to change the electrostatic interactions with an organic cation, resulting in the desired molecular assembled structures [19]. In addition, POMs with a large diameter can form an extended void space for embedding large organic cations [20]. Many supramolecular inorganic-organic hybrids based on POMs have been designed due to the structural advantages of POMs. The typical organic cations are tetrathiafulvalene and ferrocenyl derivatives [21-25]. Recently, the Nakamura group used large-sized crown ethers as organic building blocks and designed supramolecular inorganic-organic hybrids with POMs [26-28]. Crown ethers are excellent supramolecular building blocks due to their structural advantages. First, crown ethers with a large cavity can capture anilinium derivatives to form supramolecular cations through $\mathrm{N}-\mathrm{H} \cdots \mathrm{O}$ hydrogen bonding interactions $[29,30]$. Second, crown ethers are composed of carbon, oxygen, or nitrogen atoms that are exposed and can act as potential hydrogen bonding interaction sites [15].

Based on the structural advantages of POMs and crown ethers, in this study, we designed two novel supramolecular structural inorganic-organic hybrids [(3-F-4-MeAnis)([18]crown-6) $]_{2}\left[\mathrm{SMo}_{12} \mathrm{O}_{40}\right] \bullet \mathrm{CH}_{3} \mathrm{CN}$ (1) and [(4-IAnis)([18]crown-6) $]_{3}\left[\mathrm{PMo}_{12} \mathrm{O}_{40}\right] \bullet 4 \mathrm{CH}_{3} \mathrm{CN}$ (2) based on Keggin POMs and crown ethers (Scheme 1). The detailed structural characteristics of Crystals $\mathbf{1}$ and $\mathbf{2}$ will be discussed in this paper.
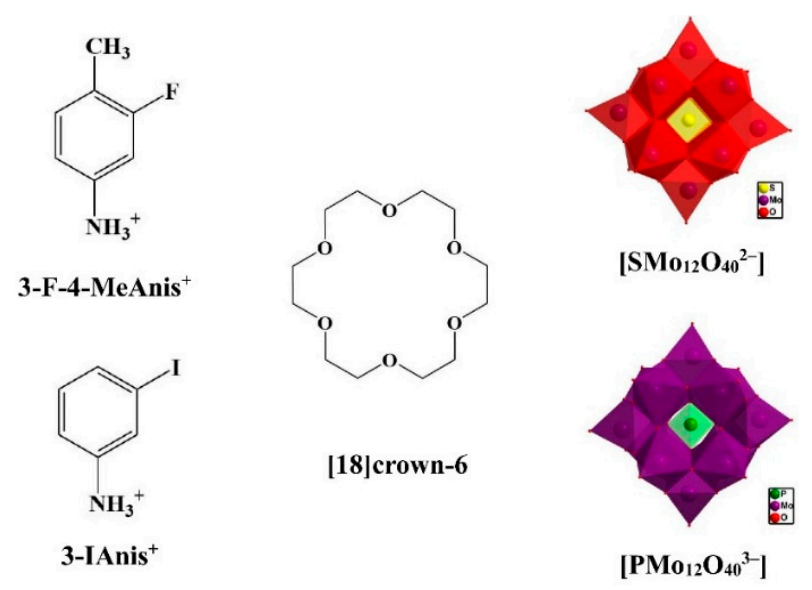

Scheme 1. The structure of $\left(3-\mathrm{F}-4-\mathrm{MeAnis}^{+}\right),\left(3-\mathrm{IAnis}^{+}\right),[18]$ crown-6 molecule, $\left[\mathrm{SMo}_{12} \mathrm{O}_{40}\right]^{2-}$, and $\left[\mathrm{PMo}_{12} \mathrm{O}_{40}\right]^{3-}$.

\section{Experimental Section}

\subsection{Materials and Measurements}

[18]Crown-6, (3-F-4-MeAnis), and (3-IAnis) were purchased from Shanghai Aladdin Bio-Chem Technology Co., LTD and were used without further purification. (3-F-4-MeAnis) and (3-IAnis), $[\mathrm{TBA}]_{2}\left[\mathrm{SMo}_{12} \mathrm{O}_{40}\right]$, and $[\mathrm{TBA}]_{3}\left[\mathrm{PMo}_{12} \mathrm{O}_{40}\right]$ salts were prepared using procedures similar to those reported previously $[19,31,32]$. IR $\left(400-7800 \mathrm{~cm}^{-1}\right)$ spectra were measured using a Thermo Scientific Nicolet 6700 FT-IR spectrometer. Elemental analyses of $C, H$, and $N$ were carried out on a CARLO ERBA 
1106 analyzer. Crystallographic data of Crystal 1 were collected using R-AXIS RAPID diffractometer with Mo K $\alpha$ radiation $(\lambda=0.071073 \mathrm{~nm})$ with a graphite monochromator at $173 \mathrm{~K}$. Crystal 2 was studied using R-AXIS RAPID diffractometer with $\mathrm{Cu} K \alpha$ radiation $(1=0.154187 \mathrm{~nm})$ with a multi-layer mirror monochromator at $173 \mathrm{~K}$. The structures were solved by direct methods (SIR 2004) and expanded using Fourier procedure, and refined on $F^{2}$ by the full-matrix least-squares method (SHELXL 97). The structures were refined using anisotropic temperature factors, except for the hydrogen atoms which were refined using the riding model with a fixed $\mathrm{C}-\mathrm{H}$ bond distance of $0.095 \mathrm{~nm}$. The crystallographic data of Crystals $\mathbf{1}$ and $\mathbf{2}$ are summarized in Table 1.

Table 1. Crystallographic parameters for $\mathbf{1}$ and 2.

\begin{tabular}{ccc}
\hline Crystal & $\mathbf{1}$ & $\mathbf{2}$ \\
\hline Formula & $\mathrm{C}_{40} \mathrm{H}_{69} \mathrm{~F}_{2} \mathrm{Mo}_{12} \mathrm{~N}_{3} \mathrm{O}_{52} \mathrm{~S}$ & $\mathrm{C}_{62} \mathrm{H}_{105} \mathrm{I}_{3} \mathrm{Mo}_{12} \mathrm{~N}_{7} \mathrm{O}_{58} \mathrm{P}$ \\
Formula weight & 2645.32 & 3439.48 \\
$\mathrm{~T} / \mathrm{K}$ & 173 & 173 \\
Crystal system & Triclinic & Monoclinic \\
Space group & $P \overline{\mathbf{1}}$ & $P 2_{1} / n$ \\
$a / \AA$ & $14.928(3)$ & $14.3880(3)$ \\
$b / \AA$ & $15.358(3)$ & $31.1929(6)$ \\
$c / \AA$ & $17.008(3)$ & $23.1485(4)$ \\
$\alpha /^{\circ}$ & $85.46(3)$ & 90 \\
$\beta /^{\circ}$ & $81.86(3)$ & $96.685(7)$ \\
$\gamma /^{\circ}$ & $80.65(3)$ & 90 \\
$V / \AA^{3}$ & $3802.5(13)$ & $10318.5(4)$ \\
$Z$ & 2 & 4 \\
$d_{\text {calc }} / \mathrm{g} \mathrm{cm}^{-3}$ & 2.310 & 2.214 \\
$\mu / \mathrm{mm}^{-1}$ & 2.045 & 19.602 \\
$\mathrm{GoF} \mathrm{on} \mathrm{F}^{2}$ & 1.223 & 1.141 \\
$R 1[I>2 \sigma(I)]$ & 0.0482 & 0.0512 \\
$w R 2[I>2 \sigma(I)]$ & 0.1268 & 0.1305 \\
\hline$R 1=\left[\Sigma\left|F_{\mathrm{o}}\right|-\left|F_{\mathrm{c}}\right|\right] /\left[\Sigma\left|F_{\mathrm{c}}\right|\right]$ and $w R 2=\left\{\left[\Sigma w\left(F_{\mathrm{o}}{ }^{2}-F_{\mathrm{c}}{ }^{2}\right)^{2}\right] /\left[\Sigma w\left(F_{\mathrm{o}}{ }^{2}\right)^{2}\right]\right\}^{1 / 2}$.
\end{tabular}

\section{2. $\left[(3-\mathrm{F}-4-\mathrm{MeAnis})([18] \text { crown-6) }]_{2}\left[\mathrm{SMo}_{12} \mathrm{O}_{40}\right] \bullet \mathrm{CH}_{3} \mathrm{CN}(\mathbf{1})\right.$}

Crystal 1 was synthesized using the standard diffusion method in an $H$-shape cell. Fifteen milliliters of saturated [TBA $]_{2}\left[\mathrm{SMo}_{12} \mathrm{O}_{40}\right] \mathrm{CH}_{3} \mathrm{CN}$ solution was added into the left side of $H$-shape cell, and $15 \mathrm{~mL}$ of acetonitrile solution with (3-F-4-MeAnis)(BF 4$)(40 \mathrm{mg}, 0.20 \mathrm{mmol})$ and [18]crown-6 (52 mg, $0.20 \mathrm{mmol})$ were placed into the right side of the $H$-shape cell. The cell was then slowly filled with acetonitrile. After two weeks, black block crystals (1) were obtained. Anal. Calcd. for $\mathrm{C}_{40} \mathrm{H}_{69} \mathrm{~F}_{2} \mathrm{Mo}_{12} \mathrm{~N}_{3} \mathrm{O}_{52} \mathrm{~S}(\%)$ : C 18.15, H 2.61, N 1.97; Found (\%): C 18.08, H 2.65, N 2.02. IR (KBr pellet, $\left.\mathrm{cm}^{-1}\right)$ : $1160(\mathrm{~m}) ; 1115(\mathrm{~s}) ; 1060(\mathrm{~m})$; 975(s); 880(m); 790(s).

\section{3. $\left[(3-I A n i s)([18] \text { crown-6) }]_{3}\left[\mathrm{PMo}_{12} \mathrm{O}_{40}\right] \bullet 4 \mathrm{CH}_{3} \mathrm{CN}(\mathbf{2})\right.$}

Crystal 2 was obtained by using the traditional solvent evaporation method. Ten milliliters of acetonitrile solution with (4-IAnis) $\left(\mathrm{BF}_{4}\right)(3 \mathrm{mg})$ and [18]crown-6 $(3 \mathrm{mg})$ were slowly added into the $10 \mathrm{~mL}[\mathrm{TBA}]_{3}\left[\mathrm{PMo}_{12} \mathrm{O}_{40}\right](20 \mathrm{mg})$ acetonitrile solution. After $15 \mathrm{~min}$ of stirring, the solution turned green and was then placed in a dark quiet place at room temperature. Green block crystals (2) were obtained about one week later. Anal. Calcd. for $\mathrm{C}_{62} \mathrm{H}_{105} \mathrm{I}_{3} \mathrm{Mo}_{12} \mathrm{~N}_{7} \mathrm{O}_{58} \mathrm{P}(\%)$ : C 21.63, H 3.05, N 2.85; Found (\%): C 21.58, H 2.98, N 2.82. IR (KBr pellet, $\mathrm{cm}^{-1}$ ): 1160(m), 1065(s), 970(s), 870(s), 790(s). 


\section{Results and Discussion}

\subsection{Crystal Structure of $\left[(3-\mathrm{F}-4-\mathrm{MeAnis})([18] \text { crown-6) }]_{2}\left[\mathrm{SMo}_{12} \mathrm{O}_{40}\right] \bullet \mathrm{CH}_{3} \mathrm{CN}\right.$ (1)}

Single crystal X-ray diffraction analysis revealed that the supramolecular Crystal $\mathbf{1}$ crystallizes in the triclinic space group $P \overline{\mathbf{1}}$ (Table 1 ). The asymmetric unit is composed of one $\left[\mathrm{SMo}_{12} \mathrm{O}_{40}\right]$ polyoxoanion, two (3-F-4-MeAnis) cations, two [18]crown-6 molecules, and one $\mathrm{CH}_{3} \mathrm{CN}$ molecule and contains as many as 179 atoms. In the crystal structure, two types of supramolecular cations with anti-paralleled arrangement can be observed as shown in Figure 1, viewed along the $c$-axis. This is different from the previously reported crystal [(2-F-4-MeAnis)([18]crown-6) $]_{2}\left[\mathrm{SMo}_{12} \mathrm{O}_{40}\right] \bullet 2 \mathrm{CH}_{3} \mathrm{CN}$ [33], which has only one type of supramolecular cation. The difference can be attributed to different crown ether and anilinium derivative building blocks. The supramolecular cations are connected through the $\mathrm{N}-\mathrm{H} \cdots \mathrm{O}$ hydrogen bonding interactions between the six oxygen atoms of the [18]crown- 6 molecules and the nitrogen atoms of (3-F-4-MeAnis) cations. The average hydrogen bonding N-O distance is 2.9274 and 2.9137 $\AA$ for Supramolecular Cations 1 and 2, respectively, as shown in Table 2, which is similar to the standard $\mathrm{N}-\mathrm{H}$... O hydrogen bonding length of $2.91 \AA$ [34], indicating that there exists a strong hydrogen bonding interaction between (3-F-4-MeAnis) cations and the [18]crown-6 molecule. The average $\mathrm{N}-\mathrm{H} \cdots \mathrm{O}$ bonding length of Supramolecular Cation 2 is shorter than that of Supramolecular Cation 1, indicating that Cation 2 has a stronger intermolecular interaction. Weak hydrogen bonding interactions $(\mathrm{C}(21)-\mathrm{H} \cdots \mathrm{O}(49)=3.447 \AA, \mathrm{H} \cdots \mathrm{O}(49)=2.58 \AA, \measuredangle \mathrm{C}-\mathrm{H} \cdots \mathrm{O}$ $\left.=149^{\circ} ; \mathrm{C}(12)-\mathrm{H} \cdots \mathrm{O}(51)=3.448 \AA, \mathrm{H} \cdots \mathrm{O}(51)=2.55 \AA, \measuredangle \mathrm{C}-\mathrm{H} \cdots \mathrm{O}=154^{\circ}\right)$ exist between Supramolecular Cations 1 and 2, which construct a supramolecular cationic dimer. This is similar to the crystal $\left[\left(m-\mathrm{FAni}^{+}\right)(\mathrm{B}[18] \text { crown-6) }]_{2}\left[\mathrm{SMo}_{12} \mathrm{O}_{40}{ }^{2-}\right][20]\right.$, which has a supramolecular dimer constructed by a crown ether and anilinium derivatives. Two nitrogen atoms (N1 and N2) are each included in the large cavity of [18]crown-6 molecules and located near its center. The dihedral angle between the (3-F-4-MeAnis) cationic plane and [18]crown-6 molecular plane constructed by six oxygen atoms is $88.489^{\circ}$ and $86.524^{\circ}$, respectively, which indicates that the N1-C13 and N2-C32 bonds are almost perpendicular to the [18]crown-6 molecular planes. The distance between the N1 (or N2) atom and the corresponding [18]crown-6 molecular plane is $0.9220 \AA$ (or $0.9017 \AA$ ).

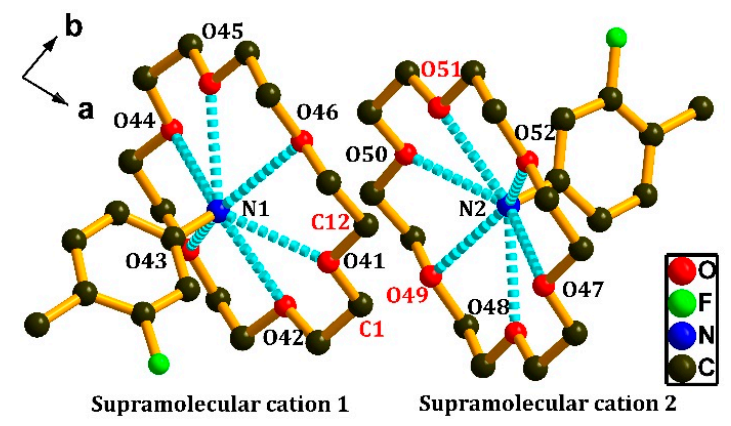

Figure 1. The structure of supramolecular cations in Crystal 1. Hydrogen atoms are omitted for clarity, and dotted cyan lines represent hydrogen bonds.

Table 2. H-Bond distances $(\AA)$ between $\mathrm{N}$ and $\mathrm{O}$ atoms in the supramolecular cation of Crystal 1.

\begin{tabular}{cccc}
\hline Supramolecular Cation 1 & Distance & Supramolecular Cation 2 & Distance \\
\hline $\mathrm{N}(1)-\mathrm{O}(41)$ & 2.8847 & $\mathrm{~N}(2)-\mathrm{O}(47)$ & 2.9704 \\
$\mathrm{~N}(1)-\mathrm{O}(42)$ & 2.9782 & $\mathrm{~N}(2)-\mathrm{O}(48)$ & 2.8732 \\
$\mathrm{~N}(1)-\mathrm{O}(43)$ & 2.9037 & $\mathrm{~N}(2)-\mathrm{O}(49)$ & 2.9799 \\
$\mathrm{~N}(1)-\mathrm{O}(44)$ & 2.9757 & $\mathrm{~N}(2)-\mathrm{O}(50)$ & 2.8553 \\
$\mathrm{~N}(1)-\mathrm{O}(45)$ & 2.8720 & $\mathrm{~N}(2)-\mathrm{O}(51)$ & 2.9414 \\
$\mathrm{~N}(1)-\mathrm{O}(46)$ & 2.9503 & $\mathrm{~N}(2)-\mathrm{O}(52)$ & 2.8622 \\
Average distance & 2.9274 & Average distance & 2.9137 \\
\hline
\end{tabular}


For $\left[\mathrm{SMo}_{12} \mathrm{O}_{40}\right]$ polyoxoanions in Crystal 1, the short $\mathrm{O} \cdots \mathrm{O}$ distance between neighboring POMs can be observed from X-ray crystal structural analysis. In the $b c$ plane (Figure 2a), the short $\mathrm{O} \cdots \mathrm{O}$ distances are $3.089 \AA(\mathrm{O}(17) \cdots \mathrm{O}(27)), 3.077 \AA(\mathrm{O}(21) \cdots \mathrm{O}(23)), 2.961 \AA(\mathrm{O}(25) \cdots \mathrm{O}(25))$, and $2.934 \AA$ $(\mathrm{O}(19) \cdots \mathrm{O}(20))$ and imply that adjacent $\left[\mathrm{SMo}_{12} \mathrm{O}_{40}\right]$ polyoxoanions have an intermolecular $\mathrm{O} \cdots \mathrm{O}$ interaction, which plays an important role in constructing the supramolecular Crystal 1. The $b c$ plane reveals close packing of $\left[\mathrm{SMo}_{12} \mathrm{O}_{40}\right]$ polyoxoanions due to the intermolecular $\mathrm{O} \cdots \mathrm{O}$ interaction as shown in Figure 2b.
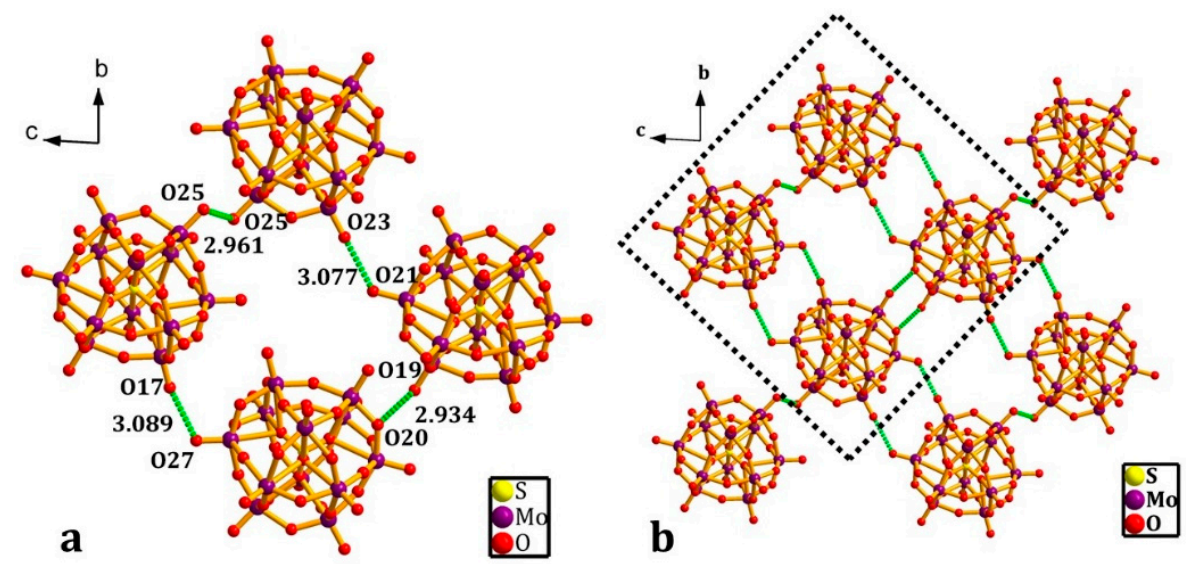

Figure 2. (a) The details of interaction between adjacent $\left[\mathrm{SMo}_{12} \mathrm{O}_{40}\right]$ polyoxoanions; (b) the packing of $\left[\mathrm{SMo}_{12} \mathrm{O}_{40}\right]$ polyoxoanions in the $b c$ plane. (a) is the enlarged view of the dotted square fragment shown in (b); the dotted green line represents the $\mathrm{O} \cdots \mathrm{O}$ interaction.

For Crystal 1, the [ $\mathrm{SMo}_{12} \mathrm{O}_{40}$ ] polyoxoanions and supramolecular cations [(3-F-4-MeAnis)([18]crown-6)] extend along the $b$-axis, as shown in Figure 3, and alternate along the $a$-axis. Multiple hydrogen bonding sites of the $\left[\mathrm{SMo}_{12} \mathrm{O}_{40}\right]$ polyoxoanions are connected through weak hydrogen bonding interactions $\left(\mathrm{C}(8)-\mathrm{H} \cdots \mathrm{O}(24)=3.335 \AA, \mathrm{H} \cdots \mathrm{O}(24)=2.51 \AA, \measuredangle \mathrm{C}-\mathrm{H} \cdots \mathrm{O}=143^{\circ} ; \mathrm{C}(10)-\mathrm{H} \cdots \mathrm{O}(16)=3.492 \AA, \mathrm{H} \cdots \mathrm{O}(16)\right.$ $=2.54 \AA, \measuredangle \mathrm{C}-\mathrm{H} \cdots \mathrm{O}=168^{\circ}$ ) with [18]crown-6 molecule (Supramolecular Cation 1). Supramolecular Cation 2 is linked to $\left[\mathrm{SMo}_{12} \mathrm{O}_{40}\right]$ polyoxoanions through weak hydrogen bonding interactions $(\mathrm{C}(37)-\mathrm{H} \cdots \mathrm{O}(21)$ $=3.312 \AA, \mathrm{H} \cdots \mathrm{O}(21)=2.52 \AA, \measuredangle \mathrm{C}-\mathrm{H} \cdots \mathrm{O}=144^{\circ}$ ) with (3-F-4-MeAnis) cation, as shown in Figure 4 . These intermolecular interactions play an important role in connecting building blocks in Crystal 1. In spite of existing hydrogen bonding interactions, Crystal $\mathbf{1}$ is unstable at room temperature.

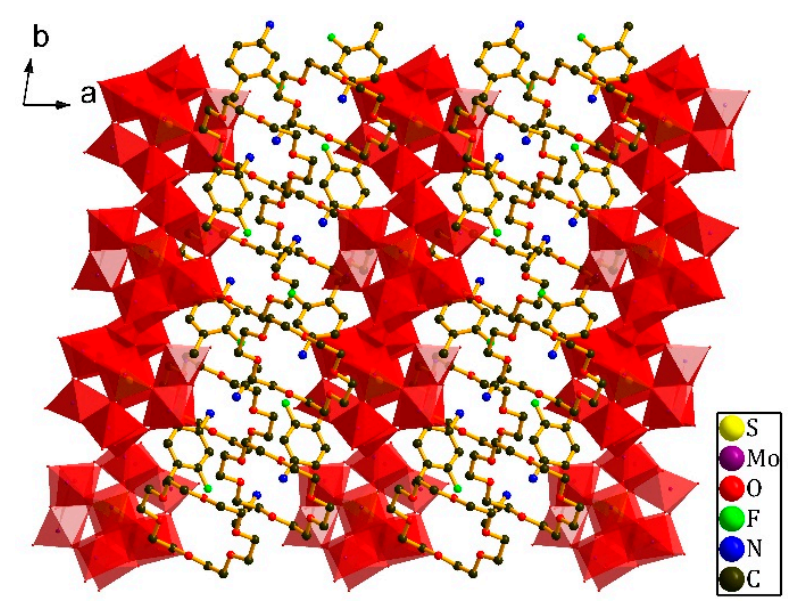

Figure 3. The packing diagram of Crystal 1, viewed along the $c$-axis. 


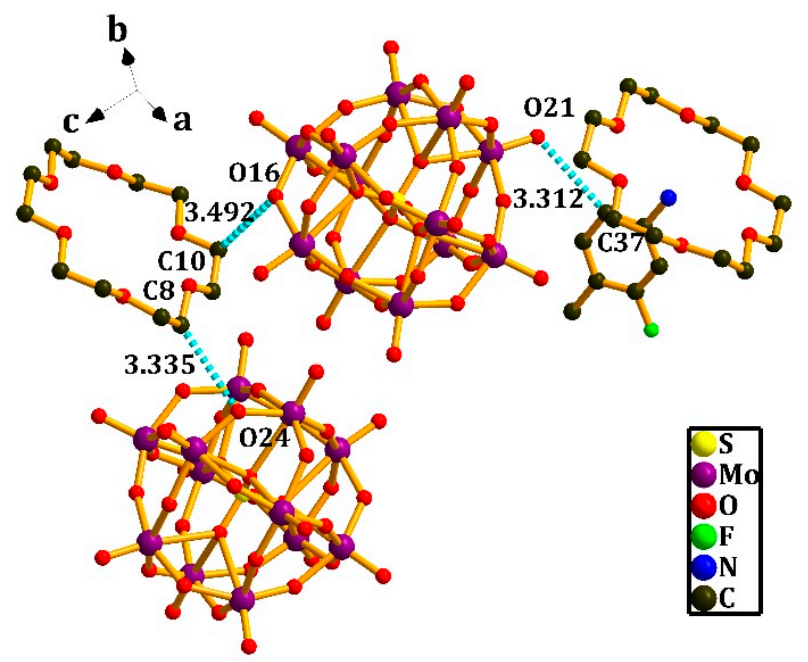

Figure 4. The weak hydrogen bonding interactions connecting $\left[\mathrm{SMo}_{12} \mathrm{O}_{40}\right]$ polyoxoanions, the [18]crown-6 molecule, and the (3-F-4-MeAnis) cation. Cyan dots represent hydrogen-bonding interactions.

\subsection{Crystal Structure of $\left[(4-I A n i s)([18] \text { crown-6) }]_{3}\left[\mathrm{PMo}_{12} \mathrm{O}_{40}\right] \bullet 4 \mathrm{CH}_{3} \mathrm{CN}\right.$ (2)}

Crystal 2 is monoclinic, space group $P 2_{1} / n$. The asymmetric unit consists of one $\left[\mathrm{PMo}_{12} \mathrm{O}_{40}\right]$ polyoxoanion, three (4-IAnis) cations, three [18]crown-6 molecules, and four $\mathrm{CH}_{3} \mathrm{CN}$ molecules and contains as many as 248 atoms. Three types of supramolecular cations are formed through $\mathrm{N}-\mathrm{H} \cdots \mathrm{O}$ hydrogen bonding interactions between the six oxygen atoms of [18]crown-6 molecule and the nitrogen atom of (4-IAnis) cation, as shown in Figure 5. This is different from previously reported crystals based on crown ethers and $\left[\mathrm{SMo}_{12} \mathrm{O}_{40}{ }^{2-}\right]$ [27], where only one or two types of differently arranged crown-ether-based supramolecular cations were present. The difference can be attributed to differently charged POMs as the building blocks. The average $\mathrm{N}-\mathrm{H} \cdots \mathrm{O}$ bond $\mathrm{N}-\mathrm{O}$ distances in Supramolecular Cations 1, 2, and 3 are 2.9004, 2.9053, and $2.9569 \AA$, respectively, as shown in Table 3. Like in Crystal 1, nitrogen atoms are located near the center of the [18]crown-6 molecule. The N-C bonds in (4-IAnis) cations are almost perpendicular to the [18]crown- 6 molecule plane defined by the six oxygen atoms. The distances between the nitrogen atoms and the [18]crown-6 molecular planes are 0.7996, 0.8427, and $1.0126 \AA$, respectively. By comparing with the average hydrogen bonding length of supramolecular cations, we found that the average hydrogen bonding length is shorter and the nitrogen atom is closer to the [18]crown-6 molecular plane, which can be attributed to the different intermolecular hydrogen bonding interactions.

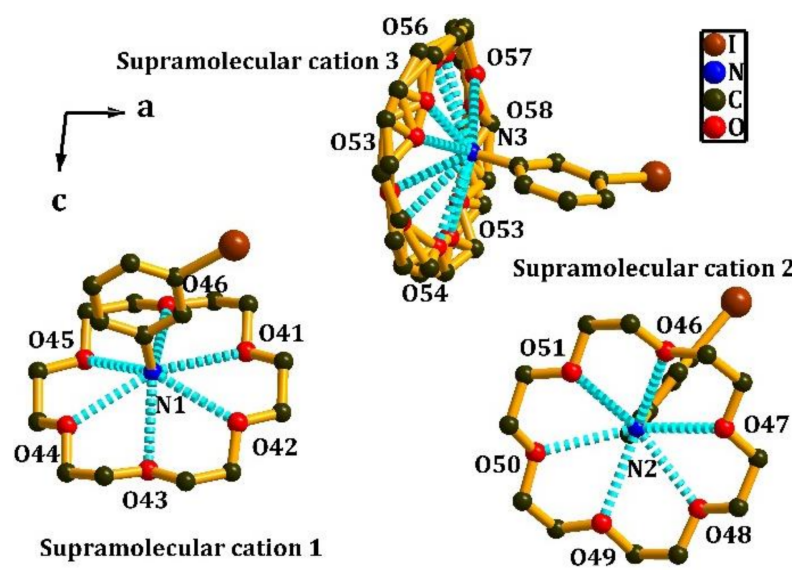

Figure 5. The structure of supramolecular cations in Crystal 2. Hydrogen atoms are omitted for clarity, and dotted cyan represents hydrogen bonds. 
Table 3. H-Bond distances $(\AA)$ between the $\mathrm{N}$ and $\mathrm{O}$ atoms in the supramolecular cation of Crystal 2.

\begin{tabular}{cccccc}
\hline Supramolecular Cation 1 & Distance & Supramolecular Cation 2 & Distance & Supramolecular Cation 3 & Distance \\
\hline $\mathrm{N}(1)-\mathrm{O}(41)$ & 2.8937 & $\mathrm{~N}(2)-\mathrm{O}(47)$ & 2.9218 & $\mathrm{~N}(3)-\mathrm{O}(53)$ & 2.9131 \\
$\mathrm{~N}(1)-\mathrm{O}(42)$ & 2.9378 & $\mathrm{~N}(2)-\mathrm{O}(48)$ & 2.9127 & $\mathrm{~N}(3)-\mathrm{O}(54)$ & 2.9691 \\
$\mathrm{~N}(1)-\mathrm{O}(43)$ & 2.9267 & $\mathrm{~N}(2)-\mathrm{O}(49)$ & 2.9147 & $\mathrm{~N}(3)-\mathrm{O}(55)$ & 2.9629 \\
$\mathrm{~N}(1)-\mathrm{O}(44)$ & 2.8978 & $\mathrm{~N}(2)-\mathrm{O}(50)$ & 2.9968 & $\mathrm{~N}(3)-\mathrm{O}(56)$ & 2.9171 \\
$\mathrm{~N}(1)-\mathrm{O}(45)$ & 2.8937 & $\mathrm{~N}(2)-\mathrm{O}(51)$ & 2.8158 & $\mathrm{~N}(3)-\mathrm{O}(57)$ & 2.8991 \\
$\mathrm{~N}(1)-\mathrm{O}(46)$ & 2.8537 & $\mathrm{~N}(2)-\mathrm{O}(52)$ & 2.8697 & $\mathrm{~N}(3)-\mathrm{O}(58)$ & 3.0802 \\
Average distance & 2.9004 & Average distance & 2.9053 & Average distance & 2.9569 \\
\hline
\end{tabular}

In Crystal 2, the short $\mathrm{O} \cdots \mathrm{O}$ distances $(4.451 \AA$ for $\mathrm{O}(25) \cdots \mathrm{O}(38)$ and $3.974 \AA \mathrm{O}(15) \cdots \mathrm{O}(25))$ between adjacent $\left[\mathrm{PMo}_{12} \mathrm{O}_{40}\right]$ polyoxoanions can be seen from the $\mathrm{X}$-ray crystal structure analysis, as shown in Figure $6 \mathrm{a}$, viewed along the $a$-axis. These results indicate that neighboring $\left[\mathrm{PMo}_{12} \mathrm{O}_{40}\right]$ polyoxoanions have an intermolecular $\mathrm{O} \cdots \mathrm{O}$ interaction that creates an infinite network of the anions in the $b c$ plane. The $\left[\mathrm{PMo}_{12} \mathrm{O}_{40}\right]$ polyoxoanions create a rhombus-shape packing arrangement in the $a c$ plane and form a large void space to embed large supramolecular cations [(4-IAnis)([18]crown-6)].

In Crystal 2, large supramolecular cations [(4-IAnis)([18]crown-6)] fill the spaces formed by six $\left[\mathrm{PMo}_{12} \mathrm{O}_{40}\right]$ polyoxoanions, and all adjacent $\left[\mathrm{PMo}_{12} \mathrm{O}_{40}\right]$ polyoxoanions are embedded into the void space constructed by the supramolecular cations [(4-IAnis)([18]crown-6)] as shown in Figure 7. The supramolecular cation [(4-IAnis)([18]crown-6)] and polyoxoanions $\left[\mathrm{PMo}_{12} \mathrm{O}_{40}\right]$ alternate along the $a$ - and $b$-axes. Each $\left[\mathrm{PMo}_{12} \mathrm{O}_{40}\right]$ polyoxoanion has a weak hydrogen bonding interaction $\left(\mathrm{C}(2)-\mathrm{H} \cdots \mathrm{O}(30)=3.458 \AA, \mathrm{H} \cdots \mathrm{O}(30)=2.49 \AA, \measuredangle \mathrm{C}-\mathrm{H} \cdots \mathrm{O}=170^{\circ} ; \mathrm{C}(20)-\mathrm{H} \cdots \mathrm{O}(18)=3.368 \AA, \mathrm{H} \cdots \mathrm{O}(18)\right.$ $\left.=2.42 \AA, \measuredangle \mathrm{C}-\mathrm{H} \cdots \mathrm{O}=165^{\circ} ; \mathrm{C}(27)-\mathrm{H} \cdots \mathrm{O}(19)=3.439 \AA, \mathrm{H} \cdots \mathrm{O}(19)=2.50 \AA, \measuredangle \mathrm{C}-\mathrm{H} \cdots \mathrm{O}=162^{\circ}\right)$ with three supramolecular cations, due to the structural characteristics of the building blocks, as shown in Figure 8. This weak noncovalent bonding interaction is indispensable in constructing Crystal 2. However, Crystal 2 is unstable at room temperature, which may be attributed to the large size of the supramolecular framework.
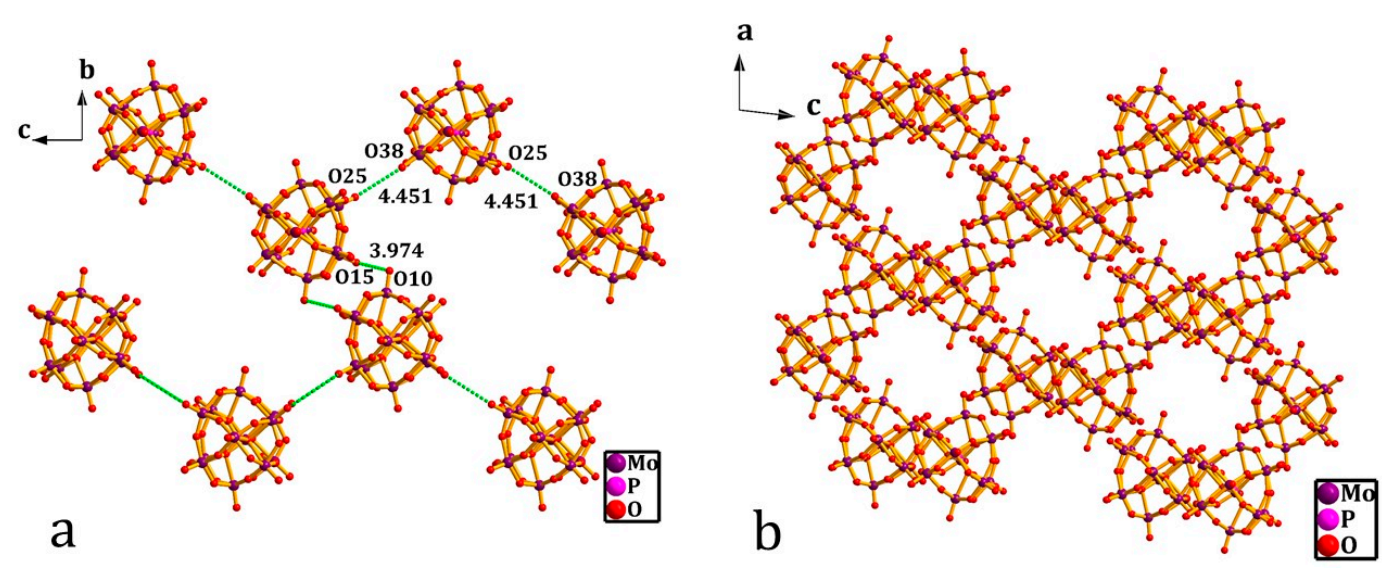

Figure 6. (a) The interaction between adjacent $\left[\mathrm{PMo}_{12} \mathrm{O}_{40}\right]$ polyoxoanions in the $b c$ plane; (b) the packing diagram of $\left[\mathrm{PMo}_{12} \mathrm{O}_{40}\right]$ polyoxoanions in the ac plane. The dotted green line represents the $\mathrm{O} \cdots \mathrm{O}$ interaction. 


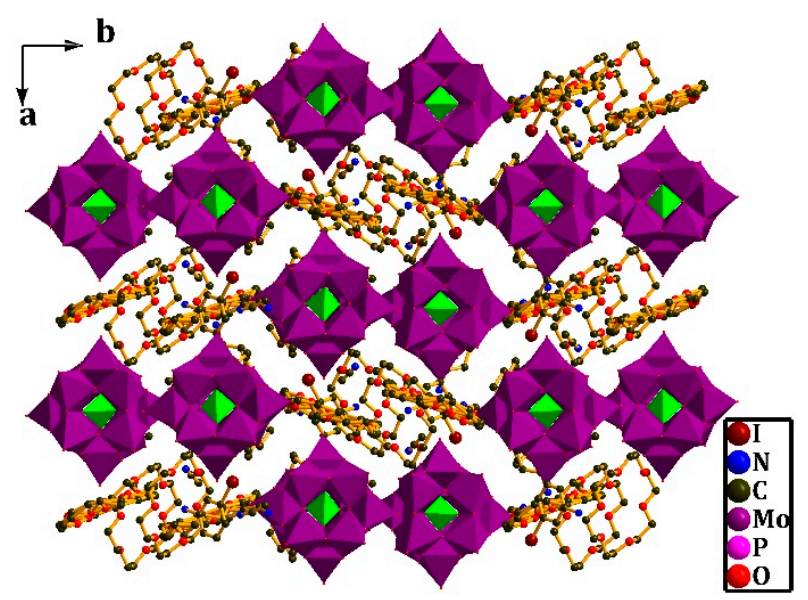

Figure 7. The packing diagram of Crystal 2, viewed along the $c$-axis.

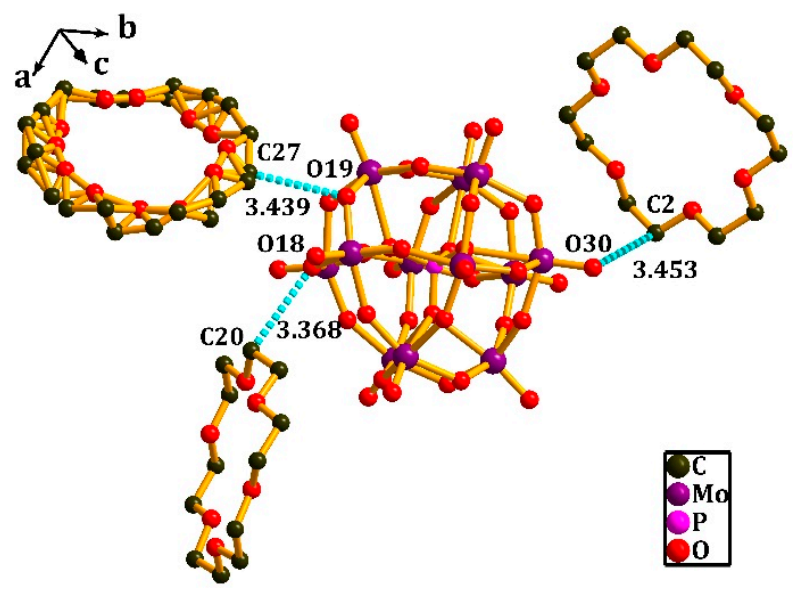

Figure 8. The weak hydrogen bonding interaction between $\left[\mathrm{PMo}_{12} \mathrm{O}_{40}\right]$ polyoxoanions and [18]crown-6 molecules. The dotted cyan represents hydrogen-bonding interaction.

\section{Conclusions}

In summary, two novel supramolecular inorganic-organic hybrids [(3-F-4-MeAnis) ([18]crown-6) $]_{2}\left[\mathrm{SMo}_{12} \mathrm{O}_{40}\right] \bullet \mathrm{CH}_{3} \mathrm{CN}$ and $\left[(4-\mathrm{IAnis})([18] \text { crown-6) }]_{3}\left[\mathrm{PMo}_{12} \mathrm{O}_{40}\right] \bullet 4 \mathrm{CH}_{3} \mathrm{CN}\right.$ have been designed utilizing the structural advantages of the building blocks. Noncovalent bonding interactions, like cement, play an important role in stabilizing the crystal structures. Different structural characteristics of the two crystals were observed via X-ray structural analysis. In Crystal 1, a dimer was constructed through weak hydrogen bonding interactions between the ([18]crown-6) molecules, and the ([18]crown-6) molecules were anti-parallel in the dimer. In Crystal 2, trivalent $\left[\mathrm{PMo}_{12} \mathrm{O}_{40}\right]$ polyoxoanions were used as inorganic building blocks. Three types of different supramolecular cations have been obtained with different arrangements. [ $\mathrm{PMo}_{12} \mathrm{O}_{40}$ ] polyoxoanions, with a rhombus-shape packing arrangement, form a large cavity, which suggests a possibility of constructing crown-ether-based supramolecular rotors in the near future.

Supplementary Materials: The following are available online at http://www.mdpi.com/2073-4352/8/2/17/s1. X-ray crystallographic files in CIF format (CCDC: Crystal 1 is 1810970, and Crystal 2 is 1810971).

Acknowledgments: The authors thank the foundation of Wuhan Textile University (Grant No. 165002) and the Hubei Key Laboratory of Biomass Fibers and Eco-dyeing \& Finishing for supporting this work.

Author Contributions: Teng Luo and Jun Zhang synthesized the two crystals; Xiao-Xia Li, Shao-Fang Lü, Jun-Jun Peng, Ming Li, and Wei Li analyzed the data and provided experimental funds, Takayoshi Nakamura provided the $\mathrm{X}$-ray diffraction machine and some chemical reagents; Jun Xiong wrote the paper. 
Conflicts of Interest: The authors declare no conflict of financial interests.

\section{References}

1. Lee, B. Developments in inorganic crystal engineering. Chem. Soc. Rev. 2004, 33, 476-489. [CrossRef] [PubMed]

2. Hollingsworth, M.D. Crystal engineering: From structure to function. Science 2002, 295, 2410-2413. [PubMed]

3. Moulton, B.; Zaworotko, M.J. From Molecules to crystal engineering: Supramolecular isomerism and polymorphism in network solids. Chem. Rev. 2001, 101, 1629-1658. [CrossRef] [PubMed]

4. Cui, Y.; Li, B.; He, H.; Zhou, W.; Chen, B.; Qian, G. Metal-organic frameworks as platforms for functional materials. Acc. Chem. Res. 2016, 49, 483-493. [CrossRef] [PubMed]

5. Sliwa, M.; Létard, S.; Malfant, I.; Nierlich, M.; Lacroix, R.G.; Asahi, T.; Masuhara, H.; Yu, P.; Nakatani, K. Design, synthesis, structural and nonlinear optical properties of photochromic crystals: Toward reversible molecular switches. Chem. Mater. 2005, 17, 4727-4735. [CrossRef]

6. Zhao, M.; Ou, S.; Wu, C.D. Porous metal-organic frameworks for heterogeneous biomimetic catalysis. Acc. Chem. Res. 2014, 47, 1199-1207. [CrossRef] [PubMed]

7. Wu, D.Q.; Shao, D.; Wei, X.Q.; Shen, F.X.; Shi, L.; Kempe, D.; Zhang, Y.Z.; Dunbar, K.R.; Wang, X.Y. Reversible on-off switching of a single-molecular magnet via a crystal chemical transformation. J. Am. Chem. Soc. 2017, 139, 11714-11717. [CrossRef] [PubMed]

8. Yan, Y.N.; Kubo, K.; Noro, S.; Akutagawa, T.; Nakamura, T. Crystal structure and physical properties of a dithiolene complex crystal with adamantine supramolecular rotator. Bull. Chem. Soc. Jpn. 2014, 87, 417-419. [CrossRef]

9. Akutagawa, T.; Sato, D.; Koshinaka, H.; Aonuma, M.; Noro, S.; Takeda, S.; Nakamura, T. Solid-state molecular rotators of anilinium and adamantylammonium in $\left[\mathrm{Ni}(\mathrm{dmit})_{2}\right]^{-}$salts with diverse magnetic properties. Inorg. Chem. 2008, 47, 5951-5962. [CrossRef] [PubMed]

10. Akutagawa, T.; Koshinaka, H.; Sato, D.; Takeda, S.; Noro, S.; Takahashi, H.; Kumai, R.; Tokura, Y.; Nakamura, T. Ferroelectricity and polarity control in solid-state flip-flop supramolecular rotators. Nat. Mater. 2009, 8, 342-347. [CrossRef] [PubMed]

11. Aakeröy, C.B.; Seddon, K.R. The hydrogen bond and crystal engineering. Chem. Soc. Rev. 1993, $22,397-407$. [CrossRef]

12. Desiraju, G.R. Hyrogen bridges in crystal engineering: Interactions without borders. Acc. Chem. Res. 2002, 35, 565-573. [CrossRef] [PubMed]

13. Aakeröy, C.B.; Fasulo, M.; Schulthesis, N.; Desper, J.; Moore, C. Structural competition between hydrogen bonds and halogen bonds. J. Am. Chem. Soc. 2007, 192, 13772-13773. [CrossRef] [PubMed]

14. Canac, Y.; Debono, N.; Lepetit, C.; Duhayon, C.; Chauvin, R. Flexible diphosphine ligands with overall charges of $0,+1$, and +2 : Critical role of the electrostatics in favoring trans over cis coordination. Inorg. Chem. 2011, 50, 10810-10819. [CrossRef] [PubMed]

15. Akutagawa, T.; Kudo, F.; Tsunashima, R.; Noro, S.; Cronin, L.; Nakamura, T. Hydrogen-bonded assemblies of two-electron reduced mix-valence $\left[\mathrm{XMo}_{12} \mathrm{O}_{40}\right](\mathrm{X}=\mathrm{P}$ and $\mathrm{Si})$ with p-phenylenediamines. Inorg. Chem. 2011, 50, 6711-6718. [CrossRef] [PubMed]

16. Ito, T. Inorganic-organic hybrid surfactant crystals: Structural aspects and functions. Crystals 2016, 6, 24. [CrossRef]

17. Xu, H.; Li, Z.; Liu, B.; Xue, G.; Hu, H.; Fu, F.; Wang, J. Charge-transfer salts via cocrystallization of the cationic ferrocenyl donor with polyoxometalate acceptors. Cryst. Growth Des. 2010, 10, 1096-1103. [CrossRef]

18. Ito, T.; Fujimoto, N.; Uchida, S.; Iijima, J.; Naruke, H.; Mizuno, N. Polyoxotungstate-surfactant layered crystal toward conductive inorganic-organic hybrid. Crystals 2012, 2, 362-373. [CrossRef]

19. Vu, T.; Bond, A.M.; Hockless, D.C.R.; Moubaraki, B.; Murray, K.S.; Lazarev, G.; Wedd, A.G. Electrochemical synthesis and structural and physical characterization of one- and two-electro-reduced forms of $\left[\mathrm{SMo}_{12} \mathrm{O}_{40}{ }^{2-}\right.$ ]. Inorg. Chem. 2001, 40, 65-72. [CrossRef] [PubMed]

20. Xiong, J.; Kubo, K.; Noro, S.; Akutagawa, T.; Nakamura, T. Self-assembled structure of inorganic-organic hybrid crystals based on Keggin polyoxometallates $\left[\mathrm{SMo}_{12} \mathrm{O}_{40}{ }^{2-}\right]$ and supramolecular cations. Cryst. Growth Des. 2016, 16, 800-807. [CrossRef] 
21. Li, Q.; Lu, Z.; Boas, J.F.; Traore, D.A.K.; Wilce, M.C.J.; Martin, L.L.; Ueda, T.; Bond, A.M. Spontaneous redox synthesis and characterization of the tetrathiafulvalene-vanadium-substituted polyoxometalate charge-transfer material $\mathrm{TTF}_{4}\left[\mathrm{SVW}_{11} \mathrm{O}_{40}\right]$ : Comparison with the Mo analogue. Inorg. Chem. 2014, 53, 10996-11006. [CrossRef] [PubMed]

22. Zhang, S.; Lu, X.; Sun, J.; Zhao, Y.; Shao, X. Honeycomb supramolecular frameworks of organic-inorganic hybrid cluster composed of cation radical and Keggin-type polyoxometalate. CrystEngComm 2015, 17, 4110-4116. [CrossRef]

23. Li, Q.; Lu, J.; Boas, J.F.; Traore, D.A.K.; Wilce, M.C.J.; Huang, F.; Martin, L.L.; Ueda, T.; Bond, A.M. Spontaneous redox synthesis of the charge transfer material $\mathrm{TTF}_{4}\left[\mathrm{SVMo}_{11} \mathrm{O}_{40}\right]$. Inorg. Chem. 2012, 51, 12929-12937. [CrossRef] [PubMed]

24. Xiong, J.; Niu, Y.; Xu, H.; Cao, G.; Liu, B.; Hu, H.; Xue, G. Charge-transfer salts based on Lindqvist and Keggin polyoxoanion acceptors and ferrocenyl cationic donors. New J. Chem. 2012, 36, 1224-1230. [CrossRef]

25. Veya, P.L.; Kochi, J.K. Structural and spectral characterization of novel charge-transfer salts of polyoxometalates and the cationic ferrocenyl donor. J. Organomet. Chem. 1995, 488, C4-C8. [CrossRef]

26. Akutagawa, T.; Endo, D.; Noro, S.; Cronin, L.; Nakamura, T. Directing organic-inorganic hybrid molecular-assemblies of polyoxometalate crown-ether complexes with supramolecular cations. Coord. Chem. Rev. 2007, 251, 2547-2561. [CrossRef]

27. Xiong, J.; Kubo, K.; Noro, S.; Akutagawa, T.; Nakamura, T. Supramolecular cations of $\left(m\right.$-halogenated-anilinium)(dibenzo[18]crown-6) in Keggin $\left[\mathrm{SMo}_{12} \mathrm{O}_{40}\right]^{2-}$ polyoxometallates. CrystEngComm 2015, 17, 856-861. [CrossRef]

28. Endo, D.; Akutagawa, T.; Kubo, K.; Noro, S.; Cronin, L.; Nakamura, T. Molecular motions and hydrogen-bonding networks in (o-aminoanilinium)-(crown ethers)-[$\left[\mathrm{PMo}_{12} \mathrm{O}_{40}\right]^{4-}$ crystals. Bull. Chem. Soc. Jpn. 2012, 85, $305-315$. [CrossRef]

29. Akutagawa, T.; Nakamura, T. Supramolecular approach for solid state Brownian rotators. Dalton Trans. 2008, 45, 6335-6345. [CrossRef] [PubMed]

30. Liu, Z.Q.; Kubo, K.; Noro, S.; Akutagawa, T.; Nakamura, T. Design of crystalline spaces for molecular rotations in crystals. Cryst. Growth Des. 2014, 14, 537-543. [CrossRef]

31. Nishihara, S.; Akutagawa, T.; Sato, D.; Takeda, S.; Noro, S.; Nakamura, T. Multirotations of (anilinium)([18]crown-6) supramolecular cation structure in magnetic salt of $\left[\mathrm{Ni}(\mathrm{dmit})_{2}\right]^{-}$. Chem. Asian J. 2007, 2, 1083-1090. [CrossRef] [PubMed]

32. Sanchez, C.; Livage, J.; Launay, J.P.; Fournier, M.; Jeannin, Y. Electron delocalization in mixed-valence molybdenum polyanions. J. Am. Chem. Soc. 1982, 104, 3194-3202. [CrossRef]

33. Xiong, J.; Lv, S.F.; Peng, J.J.; Li, M.; Li, W.; Yang, S.B. Two Inorganic-organic hybrid crystals based on polyoxometallates and supramolecular cation: Syntheses and crystal structures. Chin. J. Inorg. Chem. 2017, 33, 1649-1655.

34. Steiner, T. The hydrogen bond in the solid state. Angew. Chem. Int. Ed. 2002, 41, 48-76.

(C) 2018 by the authors. Licensee MDPI, Basel, Switzerland. This article is an open access article distributed under the terms and conditions of the Creative Commons Attribution (CC BY) license (http://creativecommons.org/licenses/by/4.0/). 